\title{
Producer Gas Generation by Agricultural Waste
}

\author{
Yogesh Parab \\ Department of Mechanical \\ Engineering \\ Vidyavardhini's College of \\ Engineering and Technology \\ Vasai, India \\ Nikhil Borse \\ Department of Mechanical \\ Engineering \\ Vidyavardhini's College of \\ Engineering and Technology \\ Vasai, India
}

\author{
Siddhesh Nijap \\ Department of Mechanical \\ Engineering \\ Vidyavardhini's College of \\ Engineering and Technology \\ Vasai, India
}

\author{
Varsha Sondagar \\ Department of Mechanical \\ Engineering \\ Vidyavardhini's College of \\ Engineering and Technology \\ Vasai, India
}

\author{
Dr. Harish Vankudre \\ Department of Mechanical \\ Engineering \\ Vidyavardhini's College of \\ Engineering and Technology \\ Vasai, India
}

\author{
Apurva Pendbhaje \\ Department of Mechanical \\ Engineering \\ Vidyavardhini's College of \\ Engineering and Technology \\ Vasai, India
}

\begin{abstract}
Gasification is a thermo- chemical which converts solid biomass into a mixture of producer gas that can be used in thermal applications like furnace, driers etc. The gasification technology is now considered to be in an advanced stage of development. It would be especially useful for small scale industries which produce biomass by-products. In this project, we have used briquettes for test using sugarcane bagasse, groundnut shell and skin, sawdust as a raw material. Once briquette formation is completed, the briquettes will be used in a Downdraft gasifier. The principle is based upon heating the briquette for a specific temperature causing chemical reaction within the gasifier and resulting formation of producer gas. The purpose of the project is not only to generate producer gas but also to enable agricultural waste disposal in the specific manner. The aim of this process is to highlight the results of gasification in Downdraft gasifier using multiple agricultural waste.
\end{abstract}

Keywords-Downdraft gasifier, Producer gas, Agricultural Waste, Producer gas efficiency,

\section{INTRODUCTION AND SCOPE}

Today, the world demand for renewable energy sources which is the key factor in the revival of the use of gasification systems, which was in strong decline after the advent of petroleum. Gasification systems are successfully applied to the production of energy from biomass. They also represent an attractive alternative to the well-established thermal treatment systems for the recovery of energy from solid wastes. Utilization of waste is the need of hour today. The waste which cannot be degraded by biochemical route like agricultural waste can be converted into useful fuel through the process called Gasification. Gasification is a thermo-chemical process which converts solid biomass into a mixture of combustible gases that can be used in thermal applications. The gasification process is a series of chemical reactions. The chemical kinetic model shows that the degree of complete reaction depends on temperature and reaction duration. Gasification of solid biomass converts it to gas often referred to as producer gas which is mainly composed of $\mathrm{CO}, \mathrm{CO}_{2}, \mathrm{CH}_{4}, \mathrm{H}_{2}$ and $\mathrm{N}_{2}$ (if the gasification agent is air).
The useful gas or combustible gas components are $\mathrm{CO}, \mathrm{H}_{2}$ and $\mathrm{CH}_{4}$, which if available in sufficient quantity [1]. Producer gas derived from biomass can be used in IC engine with some modifications. Spark ignition (SI) engine can be made to run entirely on producer gas and compression ignition (CI) engine replaces $60 \%$ - $80 \%$ fuel oil by using producer gas.[2]

\section{CONCEPT OF GASIFICATION}

Gasification is most simply incomplete combustion. It is burning solid fuels like wood or biomass without enough air to complete combustion, so the output gas still has combustion potential. The combustible gas is then piped away to burn elsewhere as needed. The downdraft gasifier process can be divided into four zones. The first, or uppermost, dry zone receives solid carbonaceous material from the top, that is dried in air drawn through the first zone. Through the first zone, the solid carbonaceous material heats up and it undergoes pyrolysis, where this biomass breaks down into charcoal, tar gases and tar vapors in liquid state. Pyrolysis is the application of heat to biomass in the absence of air/oxygen. In the combustion zone where the air/oxygen is supplied in an adequate quantity, so the most of the tar and char produced burned or cracked in combustion zone and to generate heat to run reduction zone. Combustion zone passes carbon dioxide $(\mathrm{CO} 2)$ or water vapor $(\mathrm{H} 2 \mathrm{O})$ across a bed of red-hot charcoal $(\mathrm{C})$ in the reduction zone. In the reduction zone, carbon in the hot charcoal is highly reactive with oxygen; it has such a high oxygen affinity that it strips the oxygen off water vapor and carbon dioxide, and redistributes it to as many single bond sites as possible. The oxygen is more attracted to the bond site on the $\mathrm{C}$ than to itself, thus no free oxygen can survive in its usual diatomic $\mathrm{O}_{2}$ form. All available oxygen will bond to available $\mathrm{C}$ sites as individual $\mathrm{O}$ until all the oxygen is gone. When all the available oxygen is redistributed as single atoms, reduction stops. Through this process, $\mathrm{CO}_{2}$ is reduced by carbon to produce two $\mathrm{CO}$ 
molecules, and $\mathrm{H}_{2} \mathrm{O}$ is reduced by carbon to produce $\mathrm{H} 2$ and CO.

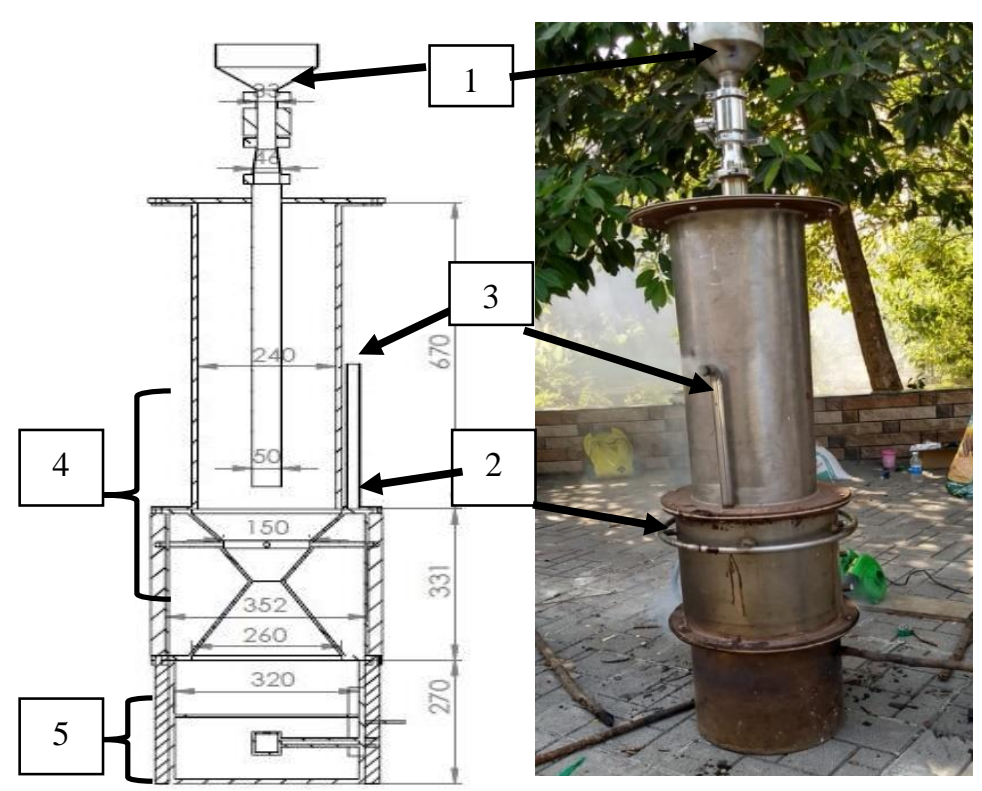

$1-$ Fuel inlet

2 - Air inlet

3 - Producer gas outlet

Fig - 1 Downdraft gasifier

\section{FACTOR AFFECTING GASIFICATION THE PROCESS. [3]}

A. Equivalence ratio - Many researchers have addressed different biomass gasification scheme with air in the gasifier. They claimed that most important factor in biomass gasification with air is the equivalence ratio and the $\mathrm{H} / \mathrm{C}$ ratio. ER defines the temperatures on the reduction zone, the tar yield and composition, as well as the heating value of the synthesis gas, whilst the H/C ratio is a measure of the steam content in the gas inside the gasifier. The conditions of the biomass gasification with air and, according to their model the ER should be in the range between 0.25 and 0.30 , the $\mathrm{H} / \mathrm{C}$ ratio around 2.2 and the temperature in the reduction zone higher than $800^{\circ} \mathrm{C}$.

B. Ash content - This refers to the inorganic component in biomass. It is expressed in the same format as the moisture content. This property is especially important under high temperature gasification as melted ash may cause problems in the reactor.

C. Elemental composition - The ash-free organic components of biomass are relatively uniform. The major components are carbon, oxygen, and hydrogen. Most biomass may also contain a small amount of nitrogen.

D. Volatile matter content - The part of the biomass that is released when the biomass is heated is referred to as the volatile matter. Volatile matter is essentially a measure of the non-water gases. Biomass feedstock contains a very high proportion of volatile organic material.

E. Moisture content - This is the amount of water in the material, expressed as a percentage of the material's weight. This weight can be on a wet basis, on a dry basis, and on a dry-and-ash basis. Biomass materials exhibit a wide range of moisture content and since this affects its value as a fuel source, it is important that the basis be stated whenever moisture content is measured. If the moisture content is excessive, the combustion process may not be self-sustaining and supplemental fuel must be used.

\section{GASIFIER FUELS}

\section{A. BIOMASS}

Every year, vast amount of biomass grows through photosynthesis by absorbing $\mathrm{CO}_{2}$ from atmosphere. When it burns, it releases the $\mathrm{CO}_{2}$ that the plants had absorbed from the atmosphere recently. Thus, the burning of biomass does not make any net addition to the earth's carbon dioxide levels.[4] Selection of Biomass is based upon the Calorific value, Carbon, Oxygen, Hydrogen and ash content which further will justify the quality of combustible composition of the producer gas. After studying from combustion characteristics of different biomass fuels [5], the preferred agricultural wastes are Sugarcane bagasse, Saw dust and Peanut shell.

1. Requirement of agricultural waste.

Physical and chemical characteristics of biomass required for briquette making are

[a] Proximate analysis

Table - I Proximate analysis for requirement of Biomass Briquette

\begin{tabular}{|c|c|c|c|c|}
\hline & $\begin{array}{l}\text { PROPERTI } \\
\text { ES }\end{array}$ & UNIT & $\begin{array}{l}\text { REQUIREME } \\
\text { NT }\end{array}$ & SOURCES \\
\hline 1 & $\begin{array}{l}\text { Moisture } \\
\text { content }\end{array}$ & $\%$ & $6-14$ & $\begin{array}{l}\text { (George K. Ngusale, } \\
\text { 2014); (Jaan Kersa, 2010); } \\
\text { (H. M. Faizal, 2010) }\end{array}$ \\
\hline 2 & Ash content & $\%$ & $\begin{array}{l}\text { Less than } 4 \% \text { to } \\
\text { avoid slagging }\end{array}$ & (H. M. Faizal, 2010) \\
\hline 3 & $\begin{array}{l}\text { Particle } \\
\text { size }\end{array}$ & $\mathrm{Mm}$ & $\begin{array}{l}\text { 1-10 mm size } \\
\text { with } \\
10-20 \% \\
\text { powdery. }\end{array}$ & $\begin{array}{l}\text { (Maria Teresa Carone, } \\
\text { 2011); (Jaan Kersa, 2010); } \\
\text { (Chou \& Lin, 2009) } \\
\text { (P.D. Grover, 1996) }\end{array}$ \\
\hline 4 & $\begin{array}{l}\text { Fixed } \\
\text { carbon }\end{array}$ & $\%$ & $9-25$ & $\begin{array}{l}\text { (C.A.Alves, 2010); (H. M. } \\
\text { Faizal, 2010) }\end{array}$ \\
\hline 5 & $\begin{array}{l}\text { Calorific } \\
\text { value }\end{array}$ & $\mathrm{MJ} / \mathrm{Kg}$ & $10-35$ & (N.S.L. Srivastava, 2014) \\
\hline 6 & $\begin{array}{l}\text { Bulk } \\
\text { density }\end{array}$ & $\mathrm{kg} / \mathrm{m}^{3}$ & More than 50 & (P.D. Grover, 1996) \\
\hline 7 & $\begin{array}{l}\text { Heating } \\
\text { value }\end{array}$ & $\mathrm{MJ} / \mathrm{Kg}$ & $12-20$ & $\begin{array}{l}\text { (Yafei Shena, 2014); } \\
\text { (Daniel Neves, 2011) }\end{array}$ \\
\hline 8 & $\begin{array}{l}\text { Volatile } \\
\text { matter }\end{array}$ & $\%$ & $50-90$ & $\begin{array}{l}\text { (Felix Fonseca Felfli, } \\
\text { 2005); (Daniel Neves H. } \\
\text { T.-B., 2011) }\end{array}$ \\
\hline
\end{tabular}

[b] Ultimate analysis 
Table - II Ultimate analysis for requirement of Biomass Briquette

\begin{tabular}{|l|l|l|l|l|}
\hline & PROPERTIES & UNIT & $\begin{array}{l}\text { REQUIREM } \\
\text { ENT }\end{array}$ & SOURCES \\
\hline 1 & Carbon & $\%$ & $40-55$ & $\begin{array}{l}\text { (Á. Ramírez-Gómez, } \\
\text { 2014); (Daya Ram } \\
\text { Nhuchhen, 2012); }\end{array}$ \\
\hline 2 & Hydrogen & $\%$ & $5-8$ & $\begin{array}{l}\text { (Á. Ramírez-Gómez, } \\
\text { 2014); (Zhengang } \\
\text { Liu, 2013) }\end{array}$ \\
\hline 3 & Oxygen & $\%$ & $35-48$ & $\begin{array}{l}\text { (Á. Ramírez-Gómez, } \\
\text { 2014) }\end{array}$ \\
\hline 4 & Nitrogen & $\%$ & $0-1$ & $\begin{array}{l}\text { (Á. Ramírez-Gómez, } \\
\text { 2014) }\end{array}$ \\
\hline
\end{tabular}

2. $\quad$ Selection of biomass. [13],[5]

Table - III Ultimate and Proximate analysis of selected biomass

\begin{tabular}{|c|c|c|c|c|c|c|c|c|c|}
\hline Biomass & \multicolumn{4}{|c|}{ Proximate analysis } & \multicolumn{5}{c|}{ Ultimate analysis } \\
\cline { 2 - 11 } & $\mathrm{VM}$ & $\mathrm{FC}$ & $\mathrm{MC}$ & $\mathrm{AC}$ & $\mathrm{C}$ & $\mathrm{O}$ & $\mathrm{H}_{2}$ & $\mathrm{~N}$ & $\mathrm{~S}$ \\
\hline Sawdust & 73.7 & 15.3 & 10.6 & 0.3 & 50.9 & 42.1 & 6.1 & 0.2 & - \\
4 & 0 & 6 & & 1 & & 3 & 3 & \\
\hline $\begin{array}{c}\text { Sugarcane } \\
\text { bagasse }\end{array}$ & $\begin{array}{c}76.6 \\
1\end{array}$ & 11.1 & 10.4 & 1.9 & 49.8 & 43.9 & 6 & 0.2 & 0.0 \\
6
\end{tabular}

\section{B. BRIQUETTES}

A briquette is a compressed block of coal dust or other combustible biomass material (e.g. charcoal, sawdust, wood chips, peat, waste) used for fuel and kindling to start a fire. Biomass briquettes: Biomass briquettes are a biofuel substitute to coal and charcoal. Briquettes are mostly used to heat industrial boilers in order to produce electricity from steam. These compressed compounds contain various organic materials, including rice husk, bagasse, ground nut shells, municipal solid waste, and agricultural waste. The raw materials are gathered and compressed into briquette in order to burn longer and make transportation of the goods easier. These briquettes are very different from charcoal because they do not have large concentrations of carbonaceous substances and added materials. Compared to fossil fuels, the briquettes produce low net total greenhouse gas emissions because the materials used are already a part of the carbon cycle. One of the most common variables of the biomass briquette production process is the way the biomass is dried out. Manufacturers can use Torre faction, carbonization, or varying degrees of pyrolysis. Researchers concluded that torr faction and carbonization are the most efficient forms of drying out biomass, but the use of the briquette determines which method should be used. Compaction is another factor affecting production. Some materials burn more efficiently if compacted at low pressures, such as corn stove grind. Other materials such as wheat and barley-straw require high amounts of pressure to produce heat. There are also different press technologies that can be used. A piston press is used to create solid briquettes for a wide array of purposes. Screw extrusion is used to compact biomass into loose, homogeneous briquettes that are substituted for coal in cofiring. The hole in the center of the briquette allows for a larger surface area, creating a higher combustion rate.[2]

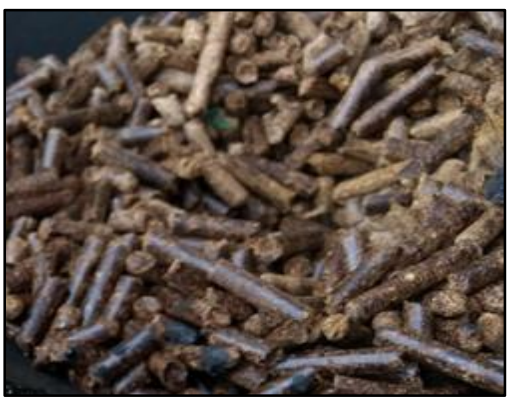

fig- 2 Sawdust briquettes

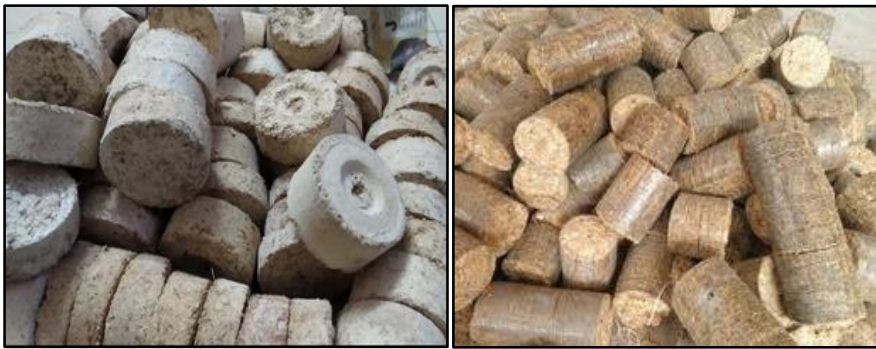

fig - 3 Peanut shell and skin briquettes, Sugarcane bagasse briquettes

\section{COAL FUEL}

According to the requirement in the gasifier the attend able temperature needs to be between $800-1200^{\circ} \mathrm{C}$. The ash content of different types of coal varies with the carbon content in the coal. Volatile matter affects the quantity of heat of the coal. Considering carbon percentage, ash content, volatile matter and availability of coal, the best type of coal suited is sub bituminous coal. The size of coal selected is 1 is to 2.5 times of biomass used, since the coal is to burn completely and biomass is to burn partially.[9].

\section{EXPERIMENT ON GASIFIER FUEL(INPUT)}

The higher heating value (HHV) can be measured in a bomb calorimeter using ASTM standard. A bomb calorimeter is a type of constant-volume calorimeter used in measuring the heat of combustion of a particular reaction. In the Bomb Calorimeter System, the whole bomb, pressurized with pure oxygen and containing a weighed mass of a sample, is submerged under a known volume of water in the Bomb Calorimeter Vessel. [7]

\section{A. PROCEDURE.}

The bomb calorimeter consists of pressurized oxygen "bomb"

two electrodes are kept in contact with the fuel inside the bomb. The oxygen bomb is placed in a container filled with 2 lit. of deionized water. The temperature of the water is measured by means of a precision thermocouple.A stirrer stirs the water continuously. Initially, the temperature change would be small as the only heat generated would be from the stirring of the water molecules. After the temperature is stabilized, the sample is fired, meaning a high voltage is sent across the electrodes and through the fuse wire. The electric current passing through the fuse wire would almost instantly ignite and combust the fuel sample in oxygen. The water absorbs the heat, released by the combustion of the sample, resulting in a sharp rise in the water temperature. The temperature continues to rise for 
some time before leveling off. The water temperature is continuously recorded till the temperature readings are stable. Knowing the heat capacity of the bomb calorimeter material, water, and of the fuse wire, one can calculate the exact amount of heat released by combustion of the same.

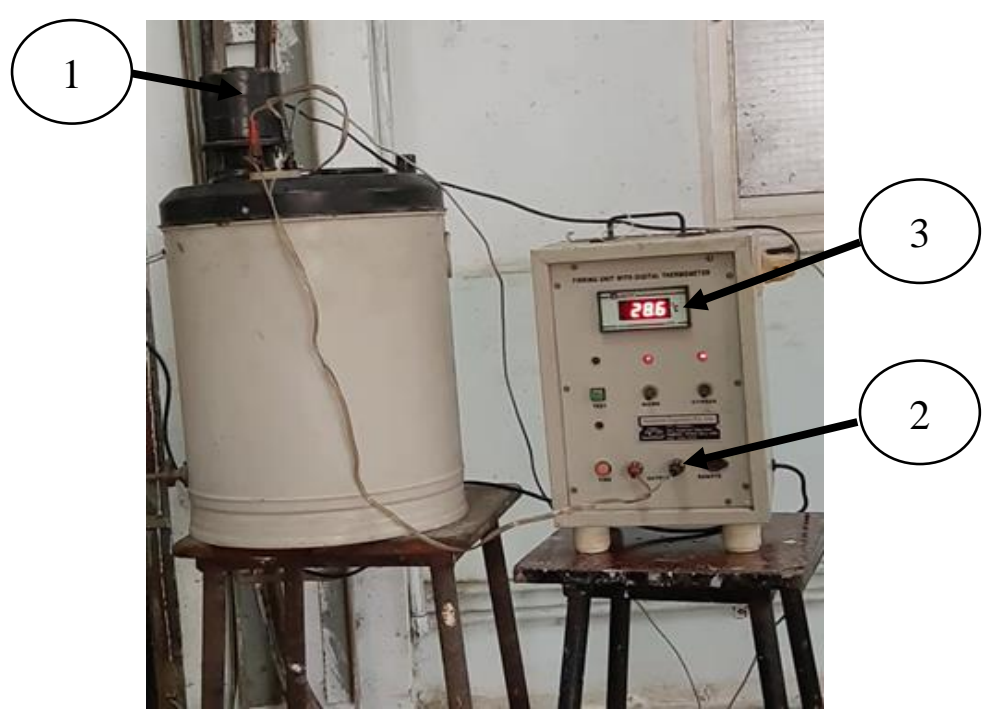

1 - Stirring motor 2 - Ignition box

3 - Temperature reader

Fig - 4 Bomb calorimeter Setup

\section{B. CALCULATE EXPERIMENTAL VALUE}

Inputs for Bomb Calorimeter -

$\mathrm{W}=$ Water equivalent of calorimeter and bomb $=$ 2215 gram.

$\mathrm{W}=$ Water equivalent of calorimeter $=2000$ gram.

$\mathrm{T}_{1}=$ Initial temperature of calorimeter.

$\mathrm{T}_{2}=$ Final temperature of calorimeter.

$\mathrm{M}=$ Weight of the sample $=0.740$ gram

- Test on Peanut skin and shell -

Table - IV Test on Peanut Skin and Shell

\begin{tabular}{|c|c|c|c|c|c|}
\hline $\begin{array}{l}\text { Time } \\
\text { in sec. }\end{array}$ & $\begin{array}{l}\text { Temp } \\
\left({ }^{0} \mathrm{C}\right)\end{array}$ & $\begin{array}{l}\text { Time in } \\
\text { sec. }\end{array}$ & $\begin{array}{l}\text { Temp } \\
\left({ }^{0} \mathrm{C}\right)\end{array}$ & $\begin{array}{l}\text { Time } \\
\text { in sec. }\end{array}$ & $\begin{array}{l}\text { Temp } \\
\left({ }^{0} \mathrm{C}\right)\end{array}$ \\
\hline 0 & 28.7 & 90 & 29.3 & 180 & 29.5 \\
\hline 30 & 29 & 120 & 29.4 & & \\
\hline 60 & 29.2 & 150 & 29.5 & & \\
\hline
\end{tabular}

- Initial temperature $-\mathrm{T}_{1}-28.7^{\circ} \mathrm{C}$

- Final temperature $-\mathrm{T}_{2}-29.5^{\circ} \mathrm{C}$

\section{CALCULATION}

- Peanut skin and shell

$$
\begin{aligned}
\mathrm{HHV} & =\frac{(W+w)\left(T_{2}-T_{1}\right)}{M} \\
& =19.06 \mathrm{MJ} / \mathrm{Kg} .
\end{aligned}
$$

\section{Peanut skin and shell $=19.06 \mathrm{MJ} / \mathrm{Kg}$}

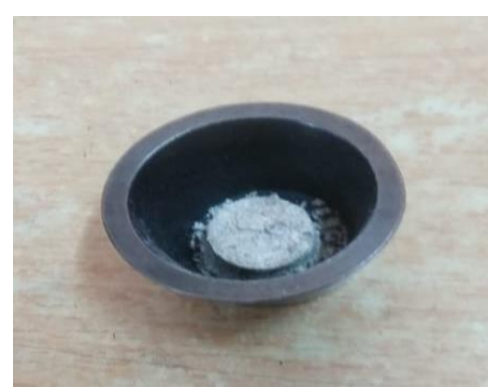

Fig - 5 Sample for test

\section{PROCEDURE TO PERFORM ON GASIFIER}

Prefill the hearth of a gasifier with charcoal, the primary aim is to fill the bottom of the reactor, as well as the reduction bell with charcoal.

Before starting the gasifier, the Top port needs to be sealed. Ash/startup port should be left open. This makes it easier to use a lighting fluid in the bottom close to grid section for preheating the coal.

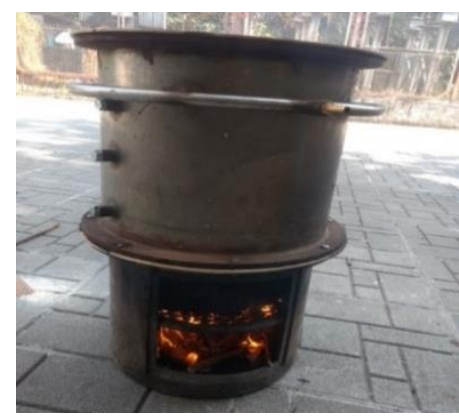

Fig - 6 Red hot condition

Recheck that all caps and plugs are in place. There should be no place for air to leak into the gasifier.

Miscellaneous operations like installing the data logger virtual instrument and placement of the thermocouple in the gasifier needs to be ensured.

According to the theoretical data the air flow and the fuel feed are maintained simultaneously once the coal achieves red hot condition

Light the charcoal on fire with a torch or small rag dropped into the reactor. Soon you should see a growing red region in the center of the bed, right above the reduction bed.

Now feed biomass to have pyrolysis so that there is tar to burn in the combustion zone. Fill the biomass to the top of the reactor.

Check to make sure all parts are seal is in order, and put on the top cover. Tighten nuts until you are sure there are no leaks.

Check the biomass level every few minutes through the fill port until you get a feel for how quickly it lowers. Do not let it go more than halfway to the nozzles before you refill. After the flare appeared largest and most consistent, chemical reaction will start taking place in throttle section. And gas (combustible) is produced. (Remember do not breathe the gas when it is unburned. After it is burned it is very clean.) 
When all samples for a day are collected, the gasifier is allowed to cool before being cleaned.

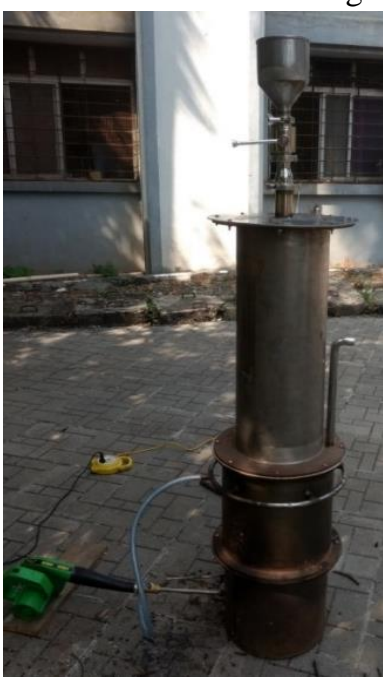

Fig - 7 Flammable producer gas

\section{A. CAUTION}

1. During the process if excess air is passed in the gasifier, it results in more proportion of oxygen leading to burning of Producer gas within chamber and can have a hazardous result.

2. Do not try to smell the Producer Gas as in the initial phase it has higher percentage of carbon monoxide which has harmful effect on humans.

\section{RESULT AND DISCUSSION}

We calculated fuel feed rate, air requirement and equivalence ratio according to our design of the downdraft gasifier. The design of the downdraft gasifier is mention in fig. (1).

Calculate Equivalence ratio $(\Phi)[8]$

1. Calculate of fuel feed rate

To find the biomass feed rate, Mf, the required power output is divided by the LHV of the biomass (LHVbm)

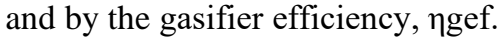

- $\mathrm{Q}$ is the gasifier's power output $=4 \mathrm{KW}$

- $\mathrm{LHVbm}$ is the lower heating value of biomass = $17.93 \mathrm{MJ} / \mathrm{Kg}$

- $\quad \prod$ is the gasifier efficiency $=0.8$

$$
\begin{aligned}
& M_{f}=\frac{Q}{l H v \times \eta} \\
& M_{f}=2.78 \times 10^{-4} \mathrm{Kg} / \mathrm{sec} \\
& M_{f}=1.005 \mathbf{K g} / \mathbf{h r}
\end{aligned}
$$

2. Air requirement of the gasifier

$M_{f_{a}}=m_{t h} \times \mathrm{ER} \times M_{f}$

$M_{f_{a}}=$ Air requirement of gasifier

$m_{t h}=$ Theoretical air requirement for complete

combustion. $=5.7[3]$

$\mathrm{ER}=$ Equivalence ratio. $=0.25[3]$

$M_{f_{a}}=3.97 \times 10^{-4} \mathrm{Kg} / \mathrm{sec}$

$M_{f_{a}}=1.42 \mathrm{Kg} / \mathrm{hr}$.
The stoichiometric ratio of air flow rate to biomass consumption rate is $5.22 \mathrm{~m} 3 \mathrm{air} / \mathrm{kg}$ of wood. [8]

- Equivalence ratio

$$
\begin{aligned}
& \Phi=\left(\frac{\text { Air Flow Rate }}{\text { Biomass Consumption Rate }}\right) / \\
& \left(\frac{\text { Air Flow Rate }}{\text { Biomass Consumption Rate }}\right) \text { Stoichiometric }
\end{aligned}
$$

$$
\Phi=0.27
$$

\section{A. PRODUCER GAS CALCULATION}

The volume percent of $\mathrm{CO}, \mathrm{CO}_{2}, \mathrm{H}_{2}, \mathrm{H}_{2} \mathrm{O}, \mathrm{CH}_{4}, \mathrm{C}_{2}$ and higher hydrocarbons, and $\mathrm{N}_{2}$ to calculate the gas energy content or to analyze gasifier operation. Gas energy content can be calculated from gas composition, or it can also be measured calorimetrically without the need to know composition. The gas must have an energy content greater than $4 \mathrm{MJ} / \mathrm{Nm} 3$ for most applications. As per the testing result from the lab defining the ultimate analysis of our briquette material, the further result would be obtained.[2] The average composition of the gas produced on dry basis is in the following range of volume percentage: $\mathrm{N}_{2}=45$ $60 \% ; \mathrm{CH}_{4}=0.25-2.5 \% ; \mathrm{H}_{2}=10-22 \% ; \mathrm{CO}=13-25 \% ; \mathrm{CO}_{2}=8$ $19 \%$ and traces of $\mathrm{C}_{2} \mathrm{H}_{2}$ and $\mathrm{C}_{2} \mathrm{H}_{4}$. [8]

Table - V Composition of Producer gas using different Briquettes [10,11,12]

\begin{tabular}{|l|l|l|l|l|l|}
\hline Material & $\mathrm{CO}$ & $\mathrm{H}_{2}$ & $\mathrm{CO}_{2}$ & $\mathrm{CH}_{4}$ & $\mathrm{~N}_{2}$ \\
\hline Sawdust & 24.04 & 14.05 & 14.66 & 2.02 & 43.62 \\
\hline $\begin{array}{l}\text { Sugarcane } \\
\text { bagasse }\end{array}$ & 19 & 18 & 10 & 2.5 & 51 \\
\hline $\begin{array}{l}\text { Peanut shell } \\
\text { and skin }\end{array}$ & 18.46 & 6.57 & 12.88 & 2 & 58.09 \\
\hline
\end{tabular}

B. CALCULATE HHV OF THE PRODUCER GAS $\mathrm{HHV}=\mathrm{CO} \% \times 322+\mathrm{H}_{2} \% \times 325+\mathrm{CH}_{4} \% \times 1031$

[2]

A. For Sawdust briquettes:

$\mathrm{HHV}=144 \mathrm{Btu} / \mathrm{scf}$

$\mathrm{HHV}=5.36 \mathrm{MJ} / \mathrm{NM}^{3}$

B. For Sugarcane Bagasse:

$\mathrm{HHV}=145 \mathrm{Btu} / \mathrm{scf}$

$\mathrm{HHV}=5.40 \mathrm{MJ} / \mathrm{NM}^{3}$

C. For Peanut Shell and Skin:

$\mathrm{HHV}=101 \mathrm{Btu} / \mathrm{scf}$

$\mathrm{HHV}=3.77 \mathrm{MJ} / \mathrm{NM}^{3}$

\section{CALCULATE GAS EFFICIENCY}

Average $1 \mathrm{~kg}$ of biomass produces about $2.5 \mathrm{~m} 3$ of producer gas

- Efficiency of Producer gas using Sawdust briquettes Average Calorific value of saw dust $=19.76 \mathrm{MJ} / \mathrm{Kg}$ [15] $\mathrm{HHV}$ of gas $=5.36 \mathrm{MJ} / \mathrm{m}^{3}$

$$
\begin{aligned}
\eta \text { gas } & =\frac{\text { calorific value of gas per } \mathrm{kg} \text { of fuel }}{\text { Average calorific value of } 1 \mathrm{~kg} \text { of fuel }} \\
\eta \mathbf{g a s} & =\mathbf{6 8} \%
\end{aligned}
$$


- Efficiency of Producer gas using Sugarcane bagasse briquettes

Average Calorific value of Sugarcane bagasse $=18.6$

$\mathrm{MJ} / \mathrm{Kg}$ [16]

$\mathrm{HHV}$ of gas $=5.4 \mathrm{MJ} / \mathrm{m}^{3}$

$\eta$ gas $=\frac{\text { calorific value of gas per } \mathrm{kg} \text { of fuel }}{\text { Average calorific value of } 1 \mathrm{~kg} \text { of fuel }}$

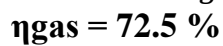

- Efficiency of Producer gas using Peanut shell and skin briquettes

Average Calorific value of Peanut shell and skin $=19.06$ $\mathrm{MJ} / \mathrm{Kg}$

$\mathrm{HHV}$ of gas $=3.77 \mathrm{MJ} / \mathrm{m}^{3}$

$\eta$ gas $=\frac{\text { calorific value of gas per } \mathrm{kg} \text { of fuel }}{\text { Average calorific value of } 1 \mathrm{~kg} \text { of fuel }}$

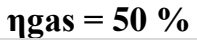

Gas composition \% using different material

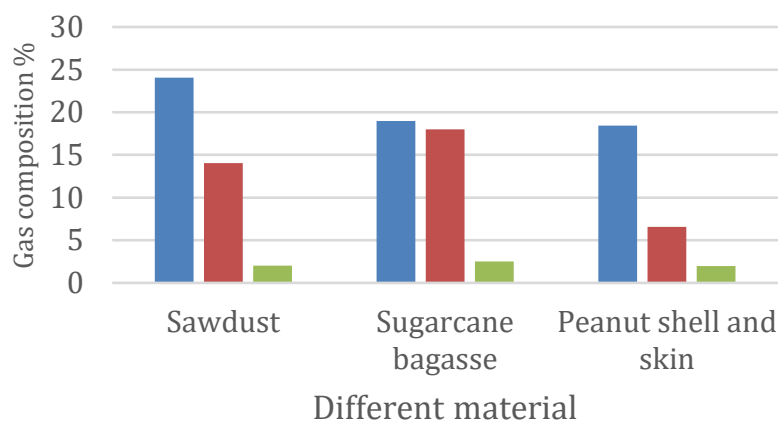

$\square \mathrm{CO} \square \mathrm{H} 2 \square \mathrm{CH} 4$

Fig - 8 Gas composition \% using different material

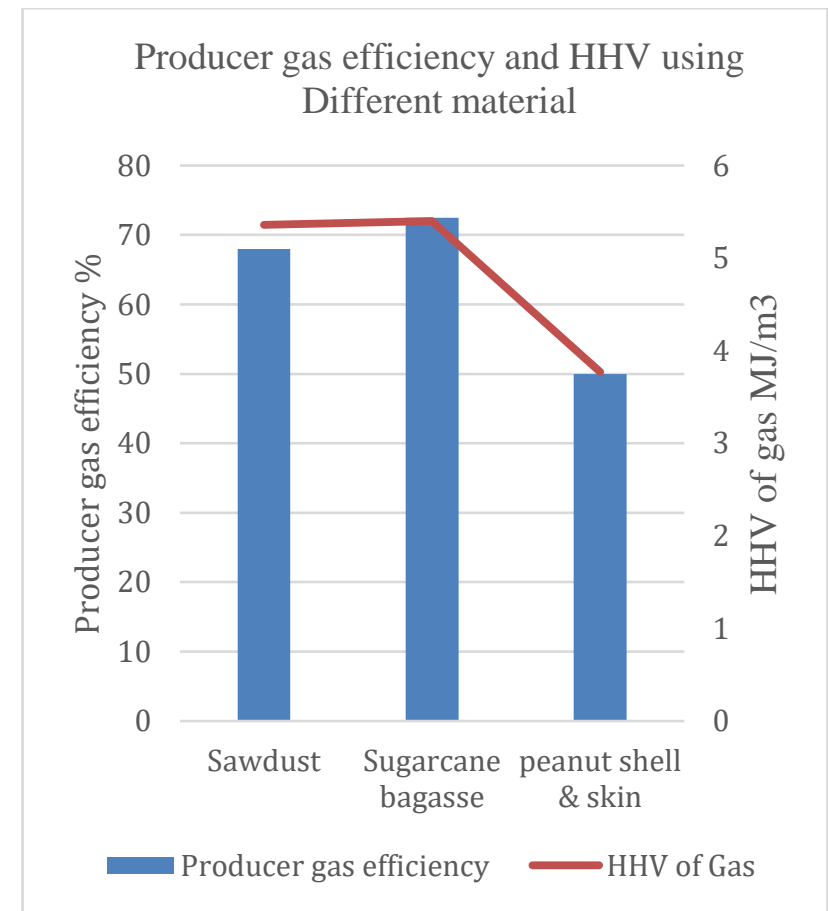

Fig - 9 Producer gas efficiency and HHV using Different material

\section{E. DISCUSSION}

The quality of Producer gas obtained from a gasifier strongly depends on the ER value, which must be below 1.0 to ensure that the incomplete combustion of fuel in gasifier. However, an excessively low ER value means below the 0.2 , results in several problems, including incomplete gasification, excessive char formation, and a low heating value of the product gas. On the other hand, too high ER value which is more than 0.5 , results in excessive formation of products of complete combustion, such as $\mathrm{CO}_{2}$ and $\mathrm{H}_{2} \mathrm{O}$, at the expense of desirable products, such as $\mathrm{CO}$ and $\mathrm{H}_{2}$. This causes a decrease in the heating value of the gas. In practical gasification systems, the ER value is normally maintained within the range of 0.20 to 0.30 . [3]

In fig 7.2 by comparing both HHV and Producer gas efficiency they are directly proportional to each other. Comparing different material, we conclude that sugarcane bagasse has greater Gas efficiency and also High heating value. In fig 7.1 Gas composition percentage using different material is there carbon monoxide percentage is greater when we using Sawdust material but hydrogen percentage is minimum comparing to the sugarcane bagasse. So that is why Sugarcane bagasse has greater higher heating value and also gas efficiency.

Hydrogen and carbon monoxide percentage of producer gas using Peanut shell and skin is minimum comparing to the other material and also has minimum gas efficiency and HHV.

As per our experimentation it is clearly seen that heating high value (HHV) of producer gas of sugarcane bagasse and sawdust does not differ by a significant ratio but there is a major difference in gas efficiency, as another factor that manipulates the calculation is calorific value of that material. Peanut shell and skin also have high calorific value comparing to the other material so their producer gas efficiency is minimum.

\section{CONCLUSION}

As per the study done during this project either theoretically or practically, various factors are to be considered while forming briquette such as Equivalence Ratio, H/C ratio, moisture content and many more. All this factor has been considered by the team during this project, after the result from labs are calculated. While manually forming briquette varying the starch and moisture content difference in calorific value was observed. The producer gas generated by this briquette might result in a producer gas with better flammable composition than the traditional method used. The expected outcome from the producer gas depending upon the practical operation has been calculated to be slightly improvised. The calculated gas to be produced has to be around 3-5 $\mathrm{MJ} / \mathrm{Nm}^{3}$. With the help of calorific value of Producer gas, we can also calculate the gas efficiency is to be around 50 to $80 \%$ of different briquette used in the project. As per the theoretical study and experimental performance if excess air is supplied through the inlet of gasifier, the increase in more atmospheric air in chamber can cause excess oxygen within the section which might result in pre combustion of producer gas before exiting through pipe which results in unusual release of heat, causing the 
producer gas quality to degrade and reduces the efficiency of the gasifier

\section{REFERENCES}

[1] Jaojaruek, K., Jarungthammachote, S., Gratuito, M.K.B., Wongsuwan, H. and Homhual, S., 2011. Experimental study of wood downdraft gasification for an improved producer gas quality through an innovative two-stage air and premixed air/gas supply approach. Bioresource technology, 102(7), pp.4834-4840.

[2] Reed, T.B. and Das, A., 1988. Handbook of biomass downdraft gasifier engine systems. Biomass Energy Foundation.

[3] Basu, P., 2010. Biomass gasification and pyrolysis: practical design and theory. Academic press.

[4] Liu, Q., Wu, S., Wang, L. and Tan, T., 2016, February. Predicting the next location: A recurrent model with spatial and temporal contexts. In Thirtieth AAAI conference on artificial intelligence.

[5] Demirbas, A., 2004. Combustion characteristics of different biomass fuels. Progress in energy and combustion science, 30(2), pp.219-230.

[6] Demirbaş, A., 1998. Fuel properties and calculation of higher heating values of vegetable oils. Fuel, 77(9-10), pp.1117-1120.

[7] Sivaramakrishnan, K. and Ravikumar, P., 2011. Determination of higher heating value of biodiesels. International Journal of Engineering Science and Technology, 3(11), pp.7981-7987.

[8] Sheth, P.N. and Babu, B.V., 2009. Experimental studies on producer gas generation from wood waste in a downdraft biomass gasifier. Bioresource technology, 100(12), pp.3127-3133.

[9] Minchener, A.J., 2005. Coal gasification for advanced power generation. Fuel, 84(17), pp.2222-2235.

[10] Zainal, Z.A., Rifau, A., Quadir, G.A. and Seetharamu, K.N., 2002. Experimental investigation of a downdraft biomass gasifier. Biomass and bioenergy, 23(4), pp.283-289.

[11] Singh, H. and Mohapatra, S.K., 2018. Production of producer gas from sugarcane bagasse and carpentry waste and its sustainable use in a dual fuel CI engine: A performance, emission, and noise investigation. Journal of the Energy Institute, 91(1), pp.43-54.

[12] Natarajan, E. and Baskara Sethupathy, S., 2015. Gasification of groundnut shells. Energy Sources, Part A: Recovery, Utilization, and Environmental Effects, 37(9), pp.980-986.

[13] Jenkins, B., Baxter, L.L., Miles Jr, T.R. and Miles, T.R., 1998. Combustion properties of biomass. Fuel processing technology, 54(13), pp.17-46.

[14] Kirsanovs, V., Blumberga, D., Veidenbergs, I., Rochas, C., Vigants, E. and Vigants, G., 2017. Experimental investigation of downdraft gasifier at various conditions. Energy Procedia, 128, pp.332-338.

[15] Aina, O.M., Adetogun, A. and Iyiola, K.A., 2009. Heat energy from value-added sawdust briquettes of albizia zygia. Ethiopian Journal of Environmental Studies and Management, 2(1).

[16] Pérez, N.P., Pedroso, D.T., Machin, E.B., Antunes, J.S., Tuna, C.E. and Silveira, J.L., 2019. Geometrical characteristics of sugarcane bagasse for being used as fuel in fluidized bed technologies. Renewable Energy, 143, pp.1210-1224. 